\title{
Continuity of home-based care for persons with dementia from formal and family caregivers' perspective
}

\begin{abstract}
Western health care policy emphasizes continuity of care for people with dementia. This paper presents formal and family caregivers' descriptions of collaboration in home-based dementia care and explores whether this collaboration inhibits or enables continuity of care and the use of the statutory individual plan. Empirical data were derived from eighteen indepth interviews with formal and family caregivers and brief fieldwork. The results reveal dynamic positions in collaborative practice and, from these positions, discrepancies in descriptions of practices and the needs of the person with dementia. Such micro-level discrepancies may serve as barriers for macro-level continuity of care objectives. To ensure continuity of care, formal and family caregivers must be aware of their positions and discuss specific expectations for information flow, involvement and care responsibilities. Individual plan can serve as a starting point for such discussions.
\end{abstract}

\section{Keywords:}

Continuity of care, dementia, formal and family caregivers, home-based care, individual plan 


\section{Introduction}

This paper is part of a larger study exploring collaboration between formal and family caregivers for people with dementia living at home. The objective for this study is to explore whether this collaboration in home-based care inhibits or enables continuity of care.

Dementia, a progressive disease with no curable treatment, leads to impairment of multiple cognitive abilities (Weiner \& Lipton, 2012). Because the number of people at risk for dementia has been increasing and people with the disease must rely heavily on health care services, dementia is a major public health problem with individual, social and economic challenges (Brodtkorb, Kirkevold, \& Ranhoff, 2008). Additionally, home-based care costs less than institutionalization. Thus, Scandinavian health policies aim for increased collaboration between formal and family caregivers within home-based care (Bergh et al., 2015; Ministry of Health and Care Services, 2009, 2013, 2015b). Several official reports emphasize family caregivers’ involvement in care as highly important for both the person with dementia and the family caregiver (Ministry of Health and Social Affairs, 2004; Norwegian Directorate of Health, 2015).

This political strategy is problematic for at least three reasons. First, as shown in many published studies, families face a major physical, psychological, social and economic burden when caring for people with dementia (Graneheim, Johansson, \& Lindgren, 2014; Murray \& McDaid, 2002). With this burden, weary caregivers are at risk for weakened collaboration in home-based care. Second, official reports describe a trend of relocation and the loss of a skilled workforce in rural municipalities (Ministry of Health and Care Services, 2015b). Such structural changes may create problems for formal health care services seeking to provide services and may thus increase the family burden. Third, official reports describe persistent problems related to dementia and continuity of care; in particular, patients and family caregivers struggle to receive information, coordinate and find the right pathways in 
formal care services (Ministry of Health and Care Services, 2009, 2014). Discontinuity indicates a failure to collaborate and entails risks for all quality health care criteria and objectives.

Official Norwegian strategies describe individual plan (IP) as one instrument to improve collaboration, ease the family burden and improve continuity of care for people with dementia (Ministry of Health and Care Services, 2009, 2015a). Although IP, as a statutory act, is unique to Norway, it relies on internationally popular ideologies that promote coordinated and individualized care services, and as such, similar plans exist in other countries (Holum, 2012a, 2013b). Although this Act has been in existence since 1999 and the Norwegian Directorate of Health has attempted to inform and simplify IP work (cf. Norwegian Directorate of Health, 2008, 2010a, 2010b, 2014), the Act is limited in clinical practice (Norwegian Directorate of Health, 2011). A supervisory report listed five problems associated with IP in home-based care: a) municipalities lack treatment and care planning procedures, b) responsibility is vaguely defined, c) collaboration with general practitioners (GPs) is unstructured, d) documentation is insufficient, and e) staff lack knowledge of IP (Norwegian Board of Health Supervision, 2014). Nonetheless, a recently published governmental health care strategy aims for all patients with dementia to be offered IP by 2020 (Ministry of Health and Care Services, 2015a). The report does not discuss these barriers.

\section{Research question and purpose}

The research question is as follows: How do formal and family caregivers experience collaboration in home-based care for people with dementia, and does this collaboration inhibit or enable continuity of care and the use of IP? 
We aimed to provide descriptions of current practice in relation to collaboration between home and formal health care services and, in particular, caregivers' experience with IP. We analyse and discuss the findings by relying on analytical concepts of positioning theory and continuity of care.

\section{Literature review}

Continuity of care

Research on continuity of care for people with dementia living at home is sparse. A recent review upholds the need for more extensive research on collaboration and networks in homebased dementia care to enable more effective care plans for these patients (Chenoweth, Kable, \& Pond, 2015).

However, a considerable amount of literature focuses on continuity of care in general, as a complex and important concept within care services (Gulliford, Naithani, \& Morgan, 2006; Haggerty et al., 2003; Heaton, Corden, \& Parker, 2012). A review by Uijen, Schers, Schellevis, and van den Bosch (2012) that focussed on continuity of care revealed overlap among many other terms and found that researchers use these terms interchangeably without definition. However, all terms involved collaboration and relationships between patients and carers (Uijen et al., 2012).

At the beginning of this century, two research programmes aimed to reduce confusion about the concept. Freeman et al. (2001) suggested six dimensions for defining continuity. Reid, Haggerty, and McKendry (2002) had simpler trisection dimensions in relational, management and informational continuity of care, which Freeman and colleagues (2007) later adopted. Relational continuity entails an ongoing therapeutic relationship between a patient and provider(s). Management continuity involves a consistent and coherent approach to managing a health condition that is responsive to a patient's changing needs. Informational 
continuity concerns the use of information on past events and personal circumstances to customize current care for each individual (Haggerty et al., 2003; Reid et al., 2002).

In a more recent study, Haggerty, Roberge, Freeman, and Beaulieu (2013b) showed how clinicians primarily emphasized the relational dimension of continuity of care. Patients took for granted coordination and information flow among formal caregivers, and they experienced continuity by receiving information, having an active role in decision-making processes and experiencing anchoring with a trusted clinician (Haggerty et al., 2013b).

Regarding continuity of care in home-based care, a Norwegian study showed that the degree of relational continuity of care was low (Gjevjon, Eika, Romoren, \& Landmark, 2014) and that managers emphasized the number of formal caregivers to strengthen continuity of care (Gjevjon, Romøren, Kjøs, \& Hellesø, 2013). One study (Gjevjon, Romøren, Bragstad, \& Hellesø, 2016) considering the patient and family caregivers’ perspective reported a high number of health care personnel involved in care. However, informed, skilled and wellknown health personnel could compensate for the problems expected with high numbers. Information flow to the next of kin was particularly important (Gjevjon et al., 2016).

In addition to 'The Freeman model' research programme previously mentioned, one study explored the evolution of the continuity of care concept along a time axis and identified three paradigms: professional, perspectivist, and partnership (Heaton et al., 2012). The first paradigm, 'professional', referred to the period before the 1990s, where formal caregivers were responsible for achieving continuity of care. The patient was a passive recipient who was delivered care. The work of Freeman et al. (2001) and Reid et al. (2002) represented a shift towards a 'perspectivist paradigm', a direction highlighting patients' and caregivers' experiences in both care processes and outcomes. The authors noted the potential emergence of a new 'partnership' paradigm. This paradigm emphasizes the relational, collective and dynamic processes within care networks. Within this kind of continuity, the empowered 
patient is important as well as inter-professional teams working together with patient and family caregivers to improve care while making health care services more efficient (Heaton et al., 2012).

This paper relies on the intertwined three-dimensional framework of continuity of care first suggested by Reid et al. (2002) in addition to the three continuity of care paradigms suggested by Heaton, Corden and Parker (2012).

\section{Individual plan}

When IP became a statutory act, governmental documents emphasized the need for rehabilitation and exemplified the patient in groups (e.g., children, disabilities, mental health and substance abuse). However, over the past decade, several new groups have been defined as potential IP users, including people with dementia (Ministry of Health and Care Services, 2009). Although some studies have explored IP within other fields, particularly Holum (2013a) exploring IP in the mental health field and Bjerkan (2015) exploring web-based solutions for IP, no studies appear to have explored IP use for people with dementia in homebased care.

Research within the disability and mental health fields shows increased collaboration and user participation (Breimo, 2014; Michaelsen, Vatne, \& Hollingen, 2011). Cancer research shows that formal caregivers do not practice IP, and three barriers to IP are identified: a) formal caregivers’ knowledge about their duty to inform and facilitate IP, b) formal caregivers' knowledge about collaboration networks within care, and c) allocation of time to perform the necessary administrative work (Sægrov, 2015). Several researchers have made conclusions about barriers such as organizational constraints and staff's (lack of) competence (Hansen, 2007; Holum, 2012b; Langhammer et al., 2013; Lidal \& Røhme, 2006). 
One study showed that the administrative level in municipalities is fairly involved, indicating management's low interest in IP work (Berven, Ludvigsen, Christensen, \& Nilssen, 2013).

\section{Materials and Methods}

\section{Study design}

This research has an exploratory, qualitative design based on the social constructive perspective (cf. Lock \& Strong, 2014). This perspective's premise is that 'reality' is context bound and that the results reflect one of several possible interpretations. The way people interpret meaning and create understanding is central to their actions. Such subjectivity in research is regarded as a resource for this study. However, the limitations are linked to the author's prior understanding that influence the study design and sampling in addition to interpretation biases in the analysis (Järvinen \& Mik-Meyer, 2005).

The design includes both a thematically textual analysis and an analysis based on analytical concepts (cf. Tjora, 2012). The results of the thematic analysis provided direction that needed to be validated and explored through further theoretical analysis led by chosen concepts. We based the analysis on semi-structured interviews with eighteen formal and family caregivers over a period of ten months, in addition to notes from brief fieldwork in which the first author followed two dementia teams for two days.

\section{Participants}

Given the research objective, we conducted purposeful sampling with the inclusion criterion of formal and family caregivers involved in home-based care for persons with dementia in rural municipalities in northern Norway. In addition to these criteria, we recruited participants regardless of gender, age or profession. 
Because the municipalities were small and transparent, we contacted seven municipalities to achieve an acceptable number of participants and to ensure confidentiality. The sample of participants from five municipalities included eleven formal caregivers and seven family caregivers. Only one participant was male, possibly because women assume formal and informal caring responsibilities more often than men do (Folbre, 2012). The formal caregivers’ ages ranged from 30 to 60. Seven were nurses, two were nursing assistants, one was a general practitioner (GP), and one was an environmental therapist. The GP had recently graduated, while the others had five to thirty years of field experience.

The family caregivers ranged from 50 to 60 years of age, and they had experience in formal health care, although only one of them had worked in clinical practice. The participants described their persons with dementia in the age range from 70 to 90 . The formal caregivers discussed patients with dementia in general in their municipality, not necessarily the same individuals referred to by family caregivers.

\section{Data collection}

The participants chose locations to meet, such as their home, their working office or a motel. We audiotaped the interviews, whose average duration was 90 minutes. In the interviews, we used a semi-structured guide that was prepared with questions about dementia symptoms, the need for formal help, measures and collaboration during health care service provision. In addition, the formal caregivers responded to question about the use of IP in clinical practice.

The guide was based on descriptions of dementia and the caregiver role from governmental health policy strategies, but it was prepared with open questions because we wanted the participants to describe their experience in ways that might touch topics that we did not consider prior to the interviews. The fieldwork involved 18 hours observing two dementia teams. Each team consisted of two formal caregivers who, in interdisciplinary 
collaboration, prepared for meetings with family caregivers and subsequently reorganized their work. We sampled these four participants among the formal caregivers who had completed interviews. The fieldwork thus supplemented the interviews examining the direct collaboration between formal caregivers and the working conditions at institutions.

\section{Data analysis}

The data for analysis were transcribed from the interviews and notes from both interviews and fieldwork. The amount of text necessitated a structural tool for analysis; we used the qualitative data analysis computer software NVIVO 10 for Windows (QSR International Pty Ltd, 2014).

The first author read the interview transcripts several times and wrote an initial interpretation of each interview. Then, she coded the key phrases in the full transcriptions of the material. She used codes close to the original text and produced a set of codes representing the meaning in the close-to-text categories. The codes were assessed relative to the fieldwork notes. For example, an important observation involved the nearby offices that hosted informal gatherings between formal caregivers. Such information was important for our understanding of the participants’ descriptions of primarily oral communication.

The codes were then interpreted within seven sorting categories regarding user participation, unmet needs, preparation for institutionalization, ethnic differences, differences between the home and institution, assurances of security and young versus old patients. For this paper, we chose to assess the 'unmet needs' category. This category was later linked to codes within the 'preparation for institutionalization' and 'assurances of security' categories. The software's search function (QSR International Pty Ltd 1999-2014, 2014) was often applied to the entire text to seek words or sentences that could be related to the codes we were using. 
From this phase, the analysis was influenced by positioning theory (cf. Van Langenhove \& Harré, 1999), which concerns what people believe about their right or duty to perform within dynamic positions and what they actually do based on those assumptions (Harre \& Slocum, 2003: 105). Understanding how formal and family caregivers position one another and persons with dementia may be important for understanding collaborative practice. The codes within the chosen categories were analysed considering possible storylines, positions, duties and rights. Each interview transcript was reread at this stage to ensure the appropriateness of the storylines within each category. Furthermore, I assessed the results against our information on the participants: gender, ethnic affiliation, municipality, age, occupation, and living status (whether they lived with the person). We did not find particular patterns of importance for this paper.

The constructed storylines and positions in addition to the theoretical concept 'continuity of care' helped to create this paper's theory-based theme 'Discrepancies between formal and family caregivers’ experience with continuity of care’.

Although the quotations presented in the results are exclusively from the interviews, we consider the fieldwork notes to be important information within the analysis, particularly the notes about formal caregivers' working conditions. To strengthen the study's reliability and validity, we show examples of the analysis process in table 1, in addition to the participants' quotations in the results in a structured way facilitating a view of our assessment.

Table 1. Example of the analysis process for the interview and fieldwork

\begin{tabular}{lllllll}
\hline Fieldwork & Key & Code & Sorting & Code & Category & Concept/the \\
observati & phrases & close to & category & close to & (inspired & me \\
on & (quotes) & text & & text & by & (inspired by \\
\hline
\end{tabular}




\begin{tabular}{|c|c|c|c|c|c|c|}
\hline & & & & & $\begin{array}{l}\text { positioni } \\
\text { ng } \\
\text { theory) }\end{array}$ & $\begin{array}{l}\text { the concept } \\
\text { 'continuity } \\
\text { of care' }\end{array}$ \\
\hline Long & 'I am & I do not & Unmet & I do not & Insecure & Discrepancies \\
\hline distances & frustrated. I & know & needs & know & position & between \\
\hline from the & do not & whom to & & whom to & & formal and \\
\hline patient and & know & ask & & ask & & family \\
\hline family & whom to & & & & & caregivers' \\
\hline caregivers' & ask, and we & & & & & experiences \\
\hline home and & do not have & & & & & of continuity \\
\hline to health & any & & & & & of care \\
\hline care & meeting & & & & & \\
\hline service & points’ & & & & & \\
\hline \multirow[t]{12}{*}{ centres } & (Family & & & & & \\
\hline & caregiver) & & & & & \\
\hline & 'I do not & I do not & & I do not & & \\
\hline & know if she & know & & know & & \\
\hline & says such & enough of & & enough of & & \\
\hline & things to be & the & & the & & \\
\hline & mean or if & symptoms & & symptoms & & \\
\hline & her & of the & & of the & & \\
\hline & behaviour & disease & & disease & & \\
\hline & is due to & & & & & \\
\hline & the disease' & & & & & \\
\hline & (Family & & & & & \\
\hline
\end{tabular}




$\begin{array}{llllll} & \text { caregiver) } & & & \\ \text { Nearby } & \text { 'Because } & \text { Everyone } & \text { Preparati } & \text { Everyone } & \text { Local } \\ \text { offices } & \text { everyone } & \text { knows } & \text { on for } & \text { knows } & \text { position } \\ \text { that hosted } & \text { knows } & \text { everyone, } & \text { institution } & \text { everyone, } & \\ \text { several } & \text { everyone, } & \text { and thus, } & \text { and thus, } & \\ \text { informal } & \text { we mostly } & \text { we mostly } & \text { we mostly } & \\ \text { gatherings } & \text { use oral } & \text { use oral } & \text { use oral } & \\ \text { between } & \text { transmissio } & \text { transmissi } & \text { transmissi } & \\ \text { formal } & \text { n' (Formal } & \text { on } & \text { on } \\ \text { caregivers. } & \text { caregiver) } & & \end{array}$

Findings: Discrepancies between formal and family caregivers' experiences with continuity of care

We present the findings within four categories that describe the positions that formal and family caregivers take in collaborating with one another. Within each position, we highlight stories about collaborative care practice, the person with dementia and IP, as shown in table 2.

Table 2. Caregiver positions with storylines.

\begin{tabular}{lllll}
\hline & Positions & Stories about & Stories about the & Stories that \\
& collaborative & person with & concern IP \\
& care practice & dementia & \\
\hline Family & Insecure & - Need & - Confused & - Enhance
\end{tabular}




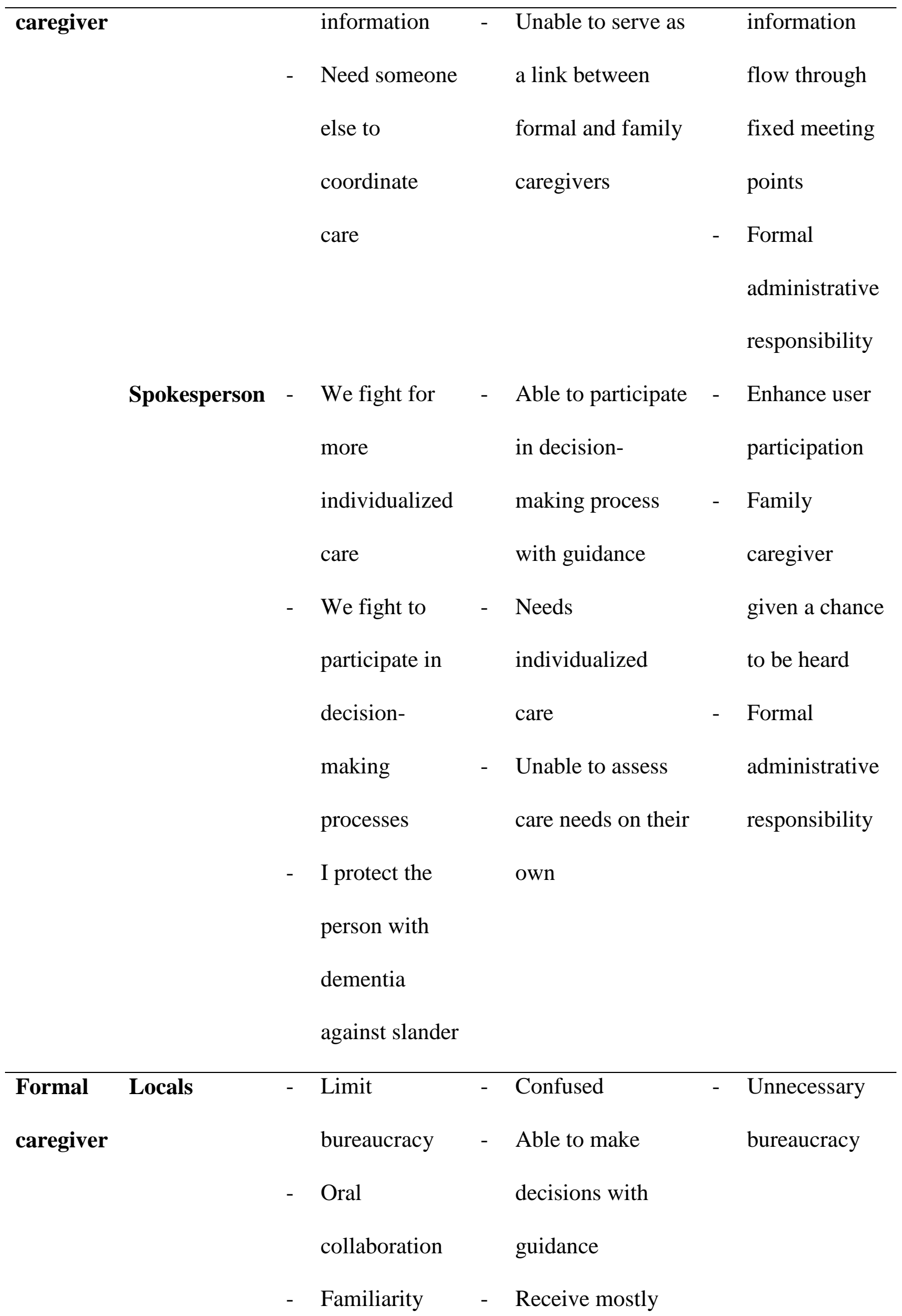




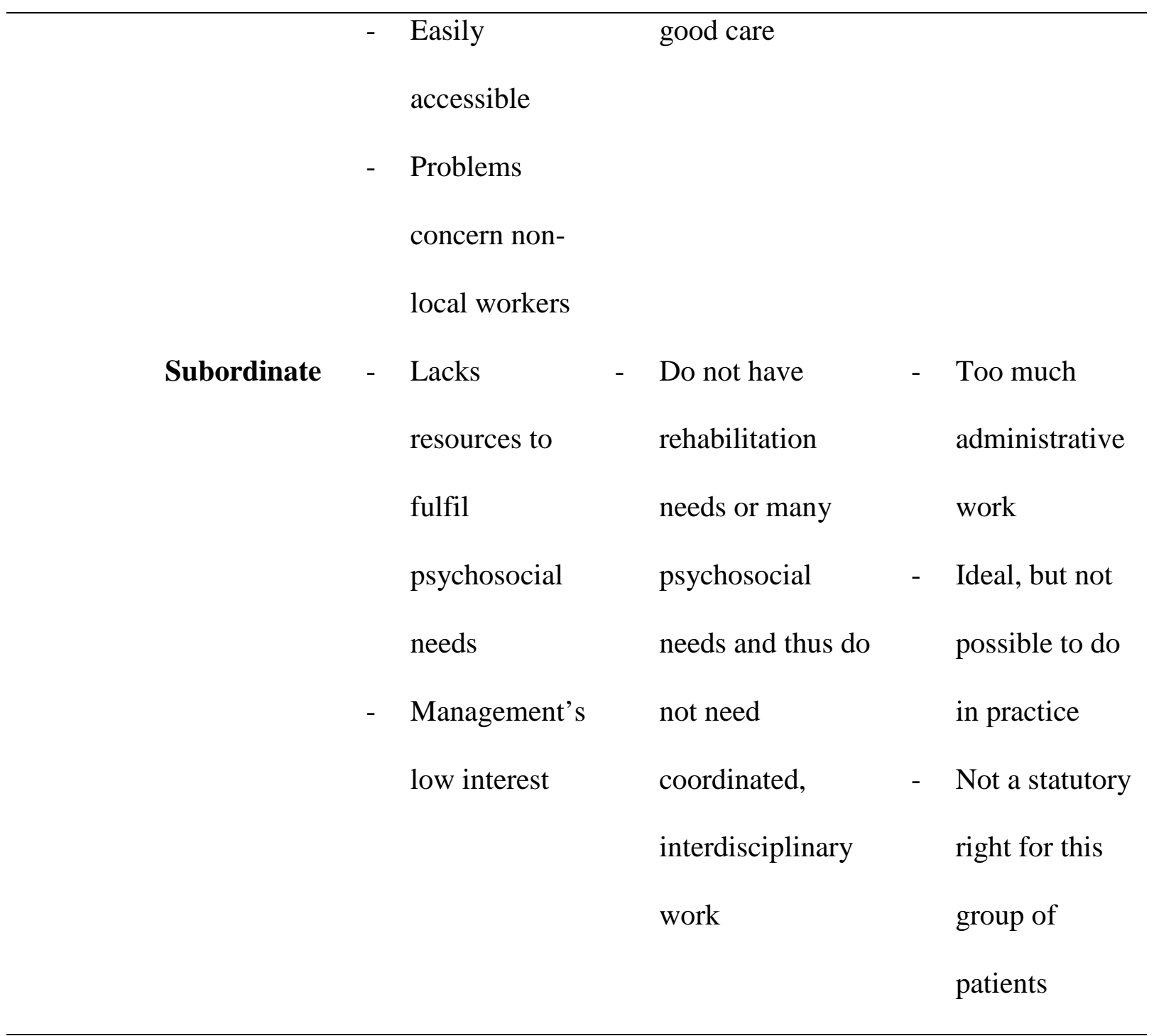

\section{Family caregivers' insecure position}

The family caregivers participated in formal caregivers' generally informal and oral surveys to assess the resources and needs of the person with dementia. However, several of these caregivers expressed that they had been left floundering in the caregiving position with many questions related to treatment and care, expected progress and safety, among other things. One caregiver explained as follows: 'I am frustrated. I do not know whom to ask, and we do not have any meeting points'. Some of the questions appeared to depend on trusting relationships to emerge. One cried when she said, 'I do not know if she says such things to be mean or if her behaviour is due to the disease'. All family caregivers expressed problems 
such as lack of information, meetings and formal primary contacts. One caregiver stated, 'There is always a new person to relate to, and this person cannot answer our questions. I am not aiming to criticize. I just want them to describe what they have done and what they are planning'. Others referred to shortcomings in care work and wished that formal health care providers could take more responsibility. One said, 'I have my own work to do. I need someone else to arrange day-care and coordinate meetings for him’.

The family caregivers positioned the persons with dementia as confused and thus unable to serve as credible sources of information. One caregiver said, 'The formal caregivers do not inform us, and she (the person with dementia) does not tell us anything'. However, in appraising their informal relationships with formal caregivers, some family caregivers explained that such relationships facilitated information flow. One family caregiver said, 'I receive help when I need it. I hope it is due to good services in the municipality and not due to my friendship with $\mathrm{X}^{\prime}$.

Four family caregivers discussed IP on their own initiative. They regarded IP as a means to address their problems with information flow, particularly given the potential establishment of a formal primary contact and regularly scheduled meetings. One of them said, 'We would benefit from a written care plan, e.g., IP’.

\section{Family caregivers' spokesperson position}

When the family caregivers experienced problems, they adopted a spokesperson position based on the person with dementia's cognitive impairment. The family caregivers felt morally obligated to take this position. One of them said, 'We have to fight to ensure the health care services that she is entitled to'.

The family caregivers positioned the persons with dementia as confused and thus unable to assess their own care needs. However, the caregivers described that with their help, 
the person with dementia could participate in care plans. All family caregivers emphasized the persons' background in care plans and the need for more individualized care. One family caregiver explained as follows: 'It seems as if the formal home-based care is a routine that everyone must follow. Their routines do not work for us'. The family caregivers expected to be included in important decisions and believed that their participation could lead to better care. However, they described several experiences of exclusion. One caregiver said, 'I wish that formal caregivers understood how important we are for patients' well-being. I wished we too got informed'. Another one stated as follows:

I have tried to say that they misunderstood her personality, but they are not interested in our opinion. They perceived her as upset and agitated, although she has always been so. They gave her medication to calm down; they doped her!

Because the municipality was small and transparent, one family caregiver indicated that she distrusted formal caregivers given the potential for slander. She said, 'I do not want them to write down anything, not yet. It is not necessary. We can collaborate without written correspondence. I do not want people to talk about her [the patient]'. The family caregiver adopted a spokesperson position to control how written documentation was managed.

Three caregivers had formally requested IP on behalf of the person with dementia, but their requests had been rejected. One family caregiver stated, 'I have requested it, and they said that such plans were not suited for my mother. I do not get it. I really need someone to coordinate and hold it together'. 


\section{Formal caregivers' local position}

Most formal caregivers identified themselves as locals. Non-locals still emphasized local knowledge as important in care. This position allowed the caregivers to act based on thorough knowledge of patients and their families. One caregiver explained as follows: 'I do not have to write down their background. I know who they are. Most of the patients we have known since we were kids'. They provided several examples of how they used this familiarity to provide individualized care. One caregiver stated, 'Having grown up here, we intuitively read their signals and know what to do’.

The local position appeared to affect the formal caregivers' understanding of documentation.

One formal caregiver explained as follows: 'Because everyone knows everyone, we mostly use oral transmission'. They referred to the large amount of ongoing, undocumented and oral collaborative work in a generally positive manner. Because of their longstanding knowledge of the person with dementia and their families, these caregivers could provide individualized, continuous care and simultaneously limit bureaucracy. One method for investigating a person's possible disease and resulting need for health care services was informal home visits. One formal caregiver stated as follows:

In a transparent municipality, we can observe people in society. We have many examples of planning home-based care in advance, keeping a room at the nursing home and so on. Then, we can help them immediately when they ask us.

Occasionally, the formal caregivers experienced problems related to the flow of information to family caregivers. As one formal caregiver declared, 'The family caregivers need fixed meeting points, and we do not handle that well. We lack routines for such work'. 
Several formal caregivers described using formal primary contact to facilitate information flow. However, because of their local position, most formal caregivers were pleased with how they collaborated in practice. One said, 'We speak with them whenever we meet them. If we do not have specific questions, we do not approach the family'. Several formal caregivers emphasized that they had given family caregivers an open invitation to approach them at any time.

However, non-local workers could pose a problem for collaboration with patients and informal caregivers, and many formal caregivers expressed an urge to observe their non-local colleagues performing their work. One respondent stated, 'For a few days, they walk with us, and we explain and show what we do. However, they often work brief periods or in part-time jobs. There is no continuity'. To improve information flow for non-locals, the local workers updated and made the patients' digital or handwritten profile cards available prior to holiday periods. However, the most problematic situations with non-locals involved foreign-born workers with permanent assignment. One respondent explained as follows:

They are decent, good workers. They smile a lot and say 'yes'. However, I do not know if they have understood the tasks or if they will do it right. They do not know the patients, and they do not know our language or culture.

These colleagues’ lack of familiarity was identified as particularly demanding when caring for people with dementia, as the disease affects patients' language function and understanding of situations.

Responding to direct questions about IP practice in this field, all formal caregivers had general knowledge of the Act. However, none of them had practised IP for persons with dementia. A large barrier to IP work in this field appeared to be the formal caregivers' 
familiarity in the municipality and their satisfaction with the existing approach to collaboration in home-based care.

Another apparent barrier was the mainly oral work. One formal caregiver explained as follows: 'Here, we are nurses, a GP, a physiotherapist, an occupational therapist and a dentist. In addition, we sometimes ask for help from a geriatric team. A phone call is often enough'. Limited bureaucracy promoted rapid decision making. A formal caregiver said, 'Because of this, the family and the patient can decide from day to day the speed of moving from homebased care to nursing home'. The belief that they could rapidly obtain approval for action from management made written care plans unnecessary.

\section{Formal caregivers' subordinate position}

When the formal caregivers described possible improvements in home-based care services, they adopted a subordinate position and referred to management's responsibility to ease resource constraints. One caregiver stated, 'Lack of time is why we do not prioritize written plan work; we would rather act than write about it'. Some formal caregivers spoke of how individualized care and further IP were ideals that did not account for resources and time available. As one caregiver explained, 'We do not have time or attention to devote to such plans. If we do write care plans, we seldom update them. Then, no one uses them anyway'. Some formal caregivers noted management's low interest in IP work. One said, 'We do not have any routines for IP'. Another explained as follows: 'Management does not request reports on such plans'.

Formal caregivers frequently noted that if they had adequate time to do their jobs, they could practise IP. However, some formal caregivers spoke of persons with dementia in a way that minimized their needs independent of the organizational resources available. Several formal caregivers spoke of patients as having lost their minds. One stated, 'Think about it, 
losing a mother while the person still is alive'. Referring to persons with dementia, another caregiver stated as follows: 'They do not have needs other than the basics, such as food, hygiene and stuff'. This mind-set appeared to exclude social, mental or spiritual needs. To consider IP for a person with dementia, they stated that the patient needed to have the potential for rehabilitation, and they regarded these persons as lacking that potential. One formal caregiver stated, 'IP is perhaps useful when there is a need for several interdisciplinary professions, but what can a physiotherapist do for a person with dementia?' Similarly, the formal caregivers deduced that coordinated work in interdisciplinary teams was unnecessary and that the Act of IP thus did not apply to these persons.

\section{Discussion}

All of our participants expressed a need for better collaboration between formal and family caregivers based on the positioning of persons with dementia as confused and unable to make important decisions on their own. However, from four dynamic positions—insecure, spokesperson, local and subordinate-they revealed discrepancies in who should participate in such collaborative practice and discrepancies in assessing the needs of people with dementia. In our further analysis, we examine whether these positions enable or inhibit relational, informational and management continuity of care.

The findings support previous studies showing that formal caregivers emphasize relational continuity of care (cf. Gjevjon et al., 2013; Haggerty, Roberge, Freeman, \& Beaulieu, 2013a). In this study, the local position was described as essential for collaboration. Although some utterances were consistent with the findings of Silviken et al. (2014) revealing relationships that are too close and thus role confusion, most family caregivers in this study appreciated the familiarity. The local position strengthens the relational dimension and thus has the potential to enhance the two other dimensions of continuity of care. Through 
rapid decisions and flexible care, the formal caregivers' organizational competence as locals appeared to compensate for management discontinuity. However, their familiarity was apparently deficient both in including non-locals and temporary workers in their local knowledge and in meeting family caregivers' needs.

The family caregivers' insecure position indicated shortcomings in information flow, meeting points and lack of individualized care, clearly referring to problems related to the informational and management aspects of continuity of care. In this position, the family caregivers asked for help, thus revealing the potential to enhance collaboration and enable continuity of care. However, the formal caregivers primarily referred to the patients and did not discuss informational links with family caregivers, a finding that fits the professional paradigm of continuity of care described by Heaton et al. (2012). The formal caregivers assumed that their local and professional expertise was sufficient to make decisions in collaboration with patients.

From the subordinate position, some formal caregivers acknowledged problems that coincided with the family caregivers' descriptions. These formal caregivers indicated that if they had more time, they would have involved family caregivers more. Such statements fit the 'partnership paradigm'; however, the formal caregivers argued that this was purely an ideal and relegated the responsibility for discontinuity to management. Nevertheless, the findings reveal how family caregivers assigned responsibility to formal caregivers and thus rejected the subordinate position.

When the family caregivers experienced severe problems, they adopted a spokesperson position, which can be understood within the 'perspectivist' paradigm. The family caregivers expected to play a crucial role in alignment with care planning for their relative. Similar to the insecure position, the spokesperson view demands partnership in care with the potential to enable continuity of care. As a spokesperson, some family caregivers 
identified IP as a solution to relational discontinuity and, in particular, informational and management discontinuity. Notably, some of them had firm knowledge of IP even if it was not practised in this field.

Because some family caregivers described negative emotions and overwhelming workloads, they could have requested IP as a solution in a burdensome situation. This finding supports studies of family burdens in general (Graneheim et al., 2014) and family burdens caused by workloads to compensate for discontinuity (cf. Bastawrous, 2013). An increased family burden can accelerate a patient's need for nursing home care, contrary to the health policy aim of increased home-based care (cf. Kirkevold, 2008; Thommesen, Normann, \& Sandvin 2008). However, formal caregivers are critical to meet such goals. In this study, the formal caregivers generally did not involve family caregivers in plans for care and sometimes disagreed with them without open discussions. We therefore interpret them as rejecting the family caregivers’ spokesperson position, thus inhibiting continuity of care.

To ease the family burden and potentially delay institutionalization, the literature describes formal caregiver responsibility as facilitating a partnership network that acknowledges family caregivers as important actors both for the persons with dementia's well-being and for the family caregivers’ own needs (Midtbø \& Kvåle, 2010). In this study, ‘the partnership paradigm’ of continuity of care does not exist. The findings for the subordinate position support Berven et al.’s (2013) study describing management's low interest in collaborative networks and further IP, in addition to Sægrov’s study (cf. Sægrov, 2015) concluding that developing a 'partnership paradigm' necessitates allocating time to performing administrative work to fulfil continuity of care goals.

Another major barrier for formalised informal and formal collaborative networks, including practising IP, is the formal caregivers' assumption that people with dementia are not the group intended for IP — a finding that fits the 'professional paradigm'. A possible 
explanation for why formal caregivers exclude people with dementia is that policymakers only recently defined this group of people as potential users of IP. An additional, more problematic explanation is the potentially maligned positioning of persons with dementia (cf. Sabat, 2006). Some formal caregivers gave statements such as 'losing her mother while the mother is still alive' and positioned the patient as a physical shell of a former person. As a physical shell, the person's background is not important. Simple and basic physical needs do not require collaborative and interdisciplinary work or IP. Such patients are at serious risk of marginalization in a care system with limited resources (Bartlett \& O'Connor, 2007; Kristiansen, Normann, Norberg, Fjelltun, \& Skaalvik, 2015; Sabat, 2006). If formal caregivers had emphasized psychosocial needs more, they could have initiated collaboration with other professions, family caregivers and non-governmental organizations (NGOs) to ensure individualized care. Such collaborative practice could have made the need for IP apparent.

In sum, although the participants value the necessity of collaboration, their dynamic positions produce subtle and visible conflicts in interaction. Formal caregivers' tendency to speak from a 'professional paradigm' is a problem when they collaborate with family caregivers whose expectations fit the 'perspectivist paradigm'. The family caregivers' questions from the 'perspectivist paradigm' could enable all three dimensions of continuity of care if the formal caregivers allow them. However, the formal caregivers' position from a 'professional paradigm' rejected the family caregivers’ positions and their requests.

Another problem is the local position. Although it strengthens the relational dimension, formal caregivers' emphasis on familiarity has severe shortcomings, as the staff includes non-locals and temporary workers. This shortcoming has consequences for both relational and informational continuity of care. In addition, the local position inhibits family 
caregivers’ participation and may accelerate maligned positioning because the position excludes the necessity of other persons' views on care needs.

Because the spokesperson position demands health care actions that the subordinate position rejects, visible conflicts appear within these positions in particular. The subordinate position thus produces an inhibiting collaborative practice that concerns management continuity of care but has severe undesirable consequences for informational and relational continuity of care. Consequently, the risk of discontinuity in care is also a threat to the overall objectives to ensure quality in health care services.

\section{Implications}

Scandinavian health care policy aims for a 'partnership paradigm' to ensure continuity of care. The findings show discontinuity and conflicting paradigms of continuity of care in practice, and such a situation poses a risk for the achievement of policy goals. If formal caregivers are generally satisfied with clinical practice, we presume that no change will occur. Given these findings, to achieve the stated political goals, formal caregivers must acknowledge family caregivers as important for home-based care for people with dementia, even though they are local and 'everyone knows each other'. This acknowledgement is essential for the 'partnership paradigm'.

An actual partnership requires time and space to consider one another's positions, possibilities and limitations for partnership in care, as well as additional resources for formal caregivers to perform such administrative and relational work. If resources are the problem, then the staff and management in health care organizations must address this problem at the political level.

In regard to IP, formal caregivers cannot chose to ignore statutory rights. Given these findings, policy makers should promptly begin to promote IP for people with dementia. 
Given the reduced cognitive capabilities of persons with dementia, formal caregivers should be particularly aware of these persons' individual and psychosocial needs. Our study findings indicate that more formalized meeting points can relieve much of the family caregivers' frustration and ease their burden. IP as a method could thus help formal and family caregivers to identify risk factors and address both the person with dementia's needs and organizational needs. IP could also address the shortcomings that arise when non-locals and temporary workers constitute an increasing proportion of the health care workforce.

Moreover, formal caregivers should be particularly aware of the maligned positioning of people with dementia. This article, which discusses positions that enable or inhibit continuity of care, may represent a starting point for necessary discussions of these topics.

\section{Conclusions}

This paper contributes to the field with empirical findings of formal and family caregivers' experiences with collaboration to ensure continuity of home-based care for persons with dementia. The paper also presents a theoretical discussion of continuity of care.

\section{Conflicts of interest}

The authors have no conflicts of interest to declare. 


\section{References}

Bartlett, R., \& O'Connor, D. (2007). From personhood to citizenship: broadening the lens for dementia practice and research. Journal of Aging Studies, 21(2), 107-118.

Bastawrous, M. (2013). Caregiver burden-A critical discussion. International Journal of Nursing Studies, 50(3), 431-441.

Bergh, S., Vossius, C., Selbæk, G., Ydstebø, A. E., Benth, J. S., Godager, G., \& Lurås., H. (2015). Ressursbruk og sykdomsforløp ved demens (REDIC) Kortversjon. [Resources and prognosis of dementia diseases]. Hamar: Alderspsykiatrisk forskningssenter, Sykehuset Innlandet.

Berven, N., Ludvigsen, K., Christensen, D. A., \& Nilssen, E. (2013). Individuell plan som virkemiddel for ledelse og samordning av tjenester i kommunene [Individual plan as a tool for management and coordination services in the municipalites] (Ministry of Local Government and Modernisation, Trans.). Bergen: Stein Rokkan senter for flerfaglige samfunnsstudier, Uni Research.

Bjerkan, J. (2015). ICT in ICP: Analysing user participation in testing of a web-based tool for Individual Care Plans (Doctoral). Norges teknisk-naturvitenskapelige universitet (NTNU), Trondheim. Retrieved from https://brage.bibsys.no/xmlui//handle/11250/1954194. (2015:250)

Breimo, J. P. (2014). Planning individually? Spotting international welfare trends in the field of rehabilitation in Norway. Scandinavian Journal of Disability Research, 18(1), 6576.

Brodtkorb, K., Kirkevold, M., \& Ranhoff, A. H. (2008). Geriatrisk sykepleie: God omsorg til den gamle pasienten [Geriatric nursing: Caring for the old patient]. Oslo: Gyldendal Akademisk. 
Chenoweth, L., Kable, A., \& Pond, D. (2015). Research in hospital discharge procedures addresses gaps in care continuity in the community, but leaves gaping holes for people with dementia: A review of the literature. Australasian Journal on Ageing, 34(1), 9-14.

Folbre, N. (2012). Should Women Care Less? Intrinsic Motivation and Gender Inequality. British Journal of Industrial Relations, 50(4), 597-619.

Freeman, G., Shepperd, S., I., R., Ehrich, K., \& Richards, S. (2001). Continutiy of care. Report of a Scoping Exercise. London: National Coordination Centre for the Service Delivery and Organization (NCCSDO).

Freeman, G., Woloshynowych, M., Baker, R., Boulton, M., Guthrie, B., Car, J., . . . Tarrant, C. (2007). Continuity of care 2006: what have we learned since 2000 and what are policy imperatives now? Report for the National Co-ordinating Centre for NHS Service Delivery and Organisation R \& D (NCCSDO). London: National Coordinating Centre for Service Delivery and Organisation.

Gjevjon, E. R., Eika, K. H., Romoren, T. I., \& Landmark, B. F. (2014). Measuring interpersonal continuity in high-frequency home healthcare services. J Adv Nurs, 70(3), 553-563.

Gjevjon, E. R., Romøren, T. I., Bragstad, L. K., \& Hellesø, R. (2016). Older Patients’ and Next of Kin’s Perspectives on Continuity in Long-Term Home Health Care. Home Health Care Management \& Practice.

Gjevjon, E. R., Romøren, T. I., Kjøs, B. Ø., \& Hellesø, R. (2013). Continuity of care in home health-care practice: two management paradoxes. Journal of Nursing Management, 21(1), 182-190. 
Graneheim, U. H., Johansson, A., \& Lindgren, B. M. (2014). Family caregivers' experiences of relinquishing the care of a person with dementia to a nursing home: insights from a meta-ethnographic study. Scandinavian Journal of Caring Sciences, 28(2), 215-224.

Gulliford, M., Naithani, S., \& Morgan, M. (2006). What is 'continuity of care'? J Health Serv Res Policy, 11(4), 248-250.

Haggerty, J. L., Reid, R. J., Freeman, G. K., Starfield, B. H., Adair, C. E., \& McKendry, R. (2003). Continuity of care: a multidisciplinary review. BMJ : British Medical Journal, 327(7425), 1219-1221.

Haggerty, J. L., Roberge, D., Freeman, G. K., \& Beaulieu, C. (2013a). Experienced Continuity of Care When Patients See Multiple Clinicians: A Qualitative Metasummary. The Annals of Family Medicine, 11(3), 262-271.

Haggerty, J. L., Roberge, D., Freeman, G. K., \& Beaulieu, C. (2013b). Experienced continuity of care when patients see multiple clinicians: a qualitative metasummary. Annals of Family Medicine, 11(3), 262-271.

Hansen, G. V. (2007). Samarbeid uten felleskap. Om individuelle planer i kommunalt psykisk helsearbeid [Collaboration without community. Individual plans in mental health care in municipalites] (PhD). Karlstad University, Karlstad. Retrieved from http://hdl.handle.net/11250/147767 (15)

Harre, R., \& Slocum, N. (2003). Disputes as complex social events: On the uses of positioning theory. Common Knowledge, 9(1), 100-118.

Heaton, J., Corden, A., \& Parker, G. (2012). 'Continuity of care’: a critical interpretive synthesis of how the concept was elaborated by a national research programme. International Journal of Integrated Care, 12e12. 
Holum, L. (2012a). “Individual plan” in a user-oriented and empowering perspective: A qualitative study of “individual plans” in Norwegian mental health services. Nordic Psychology, 64(1), 44-57.

Holum, L. (2012b). “It is a good idea, but...”: a qualitative study of implementation of 'individual plan’ in Norwegian mental health care. International Journal of Integrated Care, $12 \mathrm{e} 15$.

Holum, L. (2013a). Fra ide til virkelighet! Implementering og bruk av individuelle planer $\mathrm{i}$ psykisk helsevern : en kvalitativ studie. [From an idea to reality! The implementation and use of individual plans in mental health care: a qualitative study.] (PhD). Psykologisk institutt, Det samfunnsvitenskapelige fakultet, Universitetet i Oslo, [Oslo]. (no 431)

Holum, L. (2013b). Fra ide til virkelighet! Implementering og bruk av individuelle planer i psykisk helsevern: en kvalitativ studie. [From an idea to reality! The implementation and use of individual plans in mental health care: a qualitative study] (PhD). Psykologisk institutt, Det samfunnsvitenskapelige fakultet, Universitetet i Oslo, Oslo. (no 431)

Järvinen, M., \& Mik-Meyer, N. (2005). Indledning: Kvalitative metoder i et interaktionistisk perspektiv. [Introduction: Qualitative Methods in an Interactional Perspective.] (1 ed.). København: Hans Reizels Forlag.

Kirkevold, M. (2008). Samarbeid med pasient og pårørende [Collaboration with patients and relatives]. In M. Kirkevold, A. H. Ranhoff \& K. Brodkorb (Eds.), Geriatrisk sykepleie: God omsorg for den gamle pasienten. (pp. 123-136). Oslo: Gyldendahl akademisk.

Kristiansen, P. J. L., Normann, H. K., Norberg, A., Fjelltun, A.-M., \& Skaalvik, M. W. (2015). How do people in the early stage of Alzheimer's disease see their future? 


\section{Dementia,}

1471301215584223. http://dem.sagepub.com/content/early/2015/05/04/14713012155 84223.abstract doi:10.1177/1471301215584223

Langhammer, B., Madsen, V. H., Hellem, E., Bruusgaard, K. A., Alve, G., \& Slettebø, Å. (2013). Working with Individual Plans: Users' perspectives on the challenges and conflicts of users' needs in health and social services. Scandinavian Journal of Disability Research, 17(1), 26-45.

Lidal, E., \& Røhme, K. (2006). Individuell plan: et virkemiddel for koordinering, sammenheng og forutsigbarhet [Individual plan: A tool for coordination, coherence and predictability]. In. Bergen: Fagbokforlaget.

Lock, A., \& Strong, T. (2014). Sosial konstruksjonisme: teorier og tradisjoner [Social constructionism: Sources and sitrrings in theory and practice]. Bergen: Fagbokforlaget.

Michaelsen, R. A., Vatne, S., \& Hollingen, A. (2011). Det ble en annerledes plan [The plan became peculiar]. Tidsskrift for Psykisk Helsearbeid, 8(03), 217-226.

Midtbø, T., \& Kvåle, G. (2010). Perspektiv på samspel, kontinuitet og kvalitet i omsorgstenester for pasientar med demens i heimetenesta [Perspectives on collaboration, continuity and quality in care services for patients with dementia disease in home-based services]. Norsk Tidsskrift for Sykepleieforskning, 123-37.

Ministry of Health and Care Services. (2009). St.mld. nr. 47 (2008-2009).

Samhandlingsreformen. Rett behandling - på rett sted - til rett tid [Report no. 47 (2008-2009). The coordination reform. Proper treatment - at the right place and right time]. Oslo: Ministry of Health and Care Services, Retrieved from http://www.regjeringen.no/nb/dep/hod/dok/regpubl/stmeld/2008-2009/stmeld$\underline{\text { nr-47-2008-2009-.html?id=567201. }}$ 
Ministry of Health and Care Services. (2013). St.mld. nr 29 (2012-2013). Morgendagens omsorg [Report no. 29 (2012-2013). Future care]. Oslo: Ministry of Health and Care Services, Retrieved from http://www.regjeringen.no/pages/38301003/PDFS/STM201220130029000DDD PDFS.pdf.

Ministry of Health and Care Services. (2014). Meld. St. 11 (2014-2015) Kvalitet og pasientsikkerhet 2013. [Report no. 11 (2014-2015) Quality and safety for patients 2013]. Oslo: Regjeringen, Retrieved from https://www.regjeringen.no/nb/dokumenter/Meld-St-1120142015/id2345641/?docId=STM201420150011000DDDEPIS\&ch=1\&q=.

Ministry of Health and Care Services. (2015a). Demensplan 2020. Et mer demensvennlig samfunn. [Plan for dementia 2020. A more friendly sosiety for people with dementia]. Oslo: www.regjeringen.no, Retrieved from https://www.regjeringen.no/contentassets/3bbec72c19a04af88fa78ffb02a203da/ demensplan_2020.pdf.

Ministry of Health and Care Services. (2015b). Meld. St. 26. Fremtidens primcrhelsetjeneste - nærhet og helhet [Report no. 26 (2014-2015) The future communtiy health care services - proximity and entirity]. Oslo: www.regjeringen.no, Retrieved from https://www.regjeringen.no/contentassets/d30685b2829b41bf99edf3e3a7e95d97 /no/pdfs/stm201420150026000dddpdfs.pdf.

Ministry of Health and Social Affairs. (2004). Kvalitet i pleie- og omsorgstjenestene. Veileder til forskrift om kvalitet i pleie- og omsorgstjenestene for tjenesteyting etter kommunehelsetjenesteloven og sosialtjenesteloven. [Quality in health care services. Supervisor regulation on quality in nursing and care for intermediation by Municipal Health and Social Services Act]. Oslo: The Norwegian Directorate of Health 
Retrieved from https://helsedirektoratet.no/Lists/Publikasjoner/Attachments/122/IS1201-Kvalitet-i-pleie-og-omsorgstjenesten.pdf.

Murray, J., \& McDaid, D. (2002). Carer burden: the difficulties and rewards of care-giving. In M. Warner (Ed.), Alzheimer's disease policy and practice across Europe (pp. 1 online resource (viii, 200 s.)). Oxford: Radcliffe Medical Press.

Norwegian Board of Health Supervision. (2014). Rapport: Oppsummering av satsinga på tilsyn med helse- og omsorgstenester til eldre 2009-2012 [Report: Summary of the supervision of health care services to the elderly 2009-2012]. Oslo: Norwegian Board of Health Supervision, Ministry of Health and Care Services.

Norwegian Directorate of Health. (2008). Gjør det så enkelt som mulig. Tipshefte om Individuell plan [Simplify it. Booklet of ideas about Individual plan]. Oslo: Norwegian Directorate of Health, Retrieved from http://helsedirektoratet.no/publikasjoner/gjor-det-sa-enkelt-som-mulig-tipshefteom-individuell-plan/Publikasjoner/gjor-det-s\%c3\%a5-enkelt-som-mulig-tipshefteom-individuell-plan.pdf.

Norwegian Directorate of Health. (2010a). INDIVIDUELL PLAN 2010. Veileder til forskrift om individuell plan. [INDIVIDUAL PLAN 2010. Guideline to the Regulations about Individual Plan]. Oslo: Norwegian Directorate of Health, Retrieved from http://www.fritidforalle.no/media/66011/is-1253\%20individuell\%20plan.pdf. Norwegian Directorate of Health. (2010b). Koordinatorrollen - for deg som er eller skal bli koordinator for Individuell plan [The Coordinator - for those who are or are going to be the Coordinator of the Individual Plan]. Oslo: Norwegian Directorate of Health, Retrieved from http://helsedirektoratet.no/publikasjoner/koordinatorrollen-for-degsom-er-eller-skal-bli-koordinator-for-individuell-plan- 
/Publikasjoner/koordinatorrollen-for-deg-som-er-eller-skal-bli-koordinator-forindividuell-plan-.pdf.

Norwegian Directorate of Health. (2011). Rapport: Kartlegging av Individuell planer i landets kommuner. [Report: Mapping individual plans in the Norwegian municipalities]. Retrieved from http://helsedirektoratet.no/helse-og-omsorgstjenester/habiliteringrehabilitering/individuell-plan/Documents/kartlegging-av-individuelle-planer-ilandets-kommuner.pdf

Norwegian Directorate of Health. (2014). Tekst til nettbasert veileder for habilitering og rehabilitering, individuell plan og koordinator. Høringsforslag juni 2014 [Text to Online Tutor for Habilitation and Rehabilitation, Individual Plans and Coordinator. Draft: June 2014]. Oslo: Norwegian Directorate of Health, Retrieved from http://www.helsedirektoratet.no/Om/hoyringar/Documents/13-111555\%20Høringsutkast\%20til\%20veileder_hab_rehab_IP_koordinator\%201.juli\%2020 14.pdf.

Norwegian Directorate of Health. (2015, 06.11.2015). Brukermedvirkning. [Userparticipation]. Retrieved from https://helsedirektoratet.no/folkehelse/psykisk-helseog-rus/brukermedvirkning

QSR International Pty Ltd 1999-2014. (2014). NVIVO (Version 10 for Windows) [computer software]. Melbourne, Australia. Available from http://www.qsrinternational.com/. QSR International Pty Ltd. (2014). NVIVO 10 for Windows (NVIVO 10 for Windows ed.). Melbourne, Australia: QSR International.

Reid, R. J., Haggerty, J. L., \& McKendry, R. (2002). Defusing the confusion: Concepts and measures of continuity of health care. Ottawa: Canadian Health Services Research Foundation. 
Sabat, S. R. (2006). Malignant positioning and the predicament of people with Alzheimers's disease. In S. R. Sabat, S. J. Louw \& J. C. Hughes (Eds.), Dementia: Mind, meaning, and the person (pp. XVI, 310 s.). Oxford: Oxford University Press.

Sægrov, S. (2015). Sjukepleierans arbeid med individuell plan for kreftrammede [Nursing work with individual plan for patients diagnosed with cancer]. Tidsskrift Sykepleien Forskning, 154-61.

Silviken, A., Berntsen, G., \& Dyregrov, K. (2014). Etterlattes erfaringer med lokalt hjelpeapparat i samiske områder i Nord-Norge [Surviving relatives' experiences with local health care system in Sami areas in Northern Norway]. Sykepleien Forskning, 137-42.

Thommesen, H., Normann, T., \& Sandvin , J. T. (2008). Individuell plan. Et sesam, sesam? [Individual plan. An open sesam?] (2. utgave ed.). Oslo: Kommuneforlaget.

Tjora, A. H. (2012). Kvalitative forskningsmetoder i praksis [Qualitative research in practice] (2. utg. ed.). Oslo: Gyldendal Akademisk.

Uijen, A. A., Schers, H. J., Schellevis, F. G., \& van den Bosch, W. J. H. M. (2012). How unique is continuity of care? A review of continuity and related concepts. Family Practice, 29(3), 264-271.

Van Langenhove, L., \& Harré, R. (1999). Introducing Positioning Theory. In R. Harré \& L. Van Langenhove (Eds.), Positioning Theory (pp. 14-31). Oxford: Blackwell Publisher Ltd.

Weiner, M. F., \& Lipton, A. M. (2012). Clinical manual of Alzheimer disease and other dementias. Arlington, VA: American Psychiatric Publishing. 